\title{
Thematic Lesson of Mathematics of Light Mentally Disabled Children in Special School
}

\author{
Puji Wardaya \\ Master Program of Mathematics \\ Education \\ Sebelas Maret University \\ Surakarta, Indonesia \\ puji.wardaya@gmail.com
}

\author{
Diari Indiati \\ Department of Mathematics \\ Sebelas Maret University \\ Surakarta, Indonesia
}

\author{
Budiyono \\ Master Program of Mathematics \\ Education \\ Sebelas Maret University \\ Surakarta, Indonesia
}

\begin{abstract}
This research activity aimed to describe the implementation of mathematics thematic lesson for light mentally disabled children at the seventh grade of SLB Negeri Purworejo. This research includes the management of mathematic thematic learning and classroom management. This research uses descriptive qualitative research method with case study approach strategy. The population of the research is the seventh grade students of SLB Negeri Purworejo. The techniques of collecting the data are uses observation, field notes, interviews, and documents. The techniques of analyzing the data are consist of reducing data, presenting data and concluding. The results obtained in this study are: (1) all aspects in management of thematic learning in children with light mentally disabled covering the preparation stage, implementation, implementation and assessment of learning is not maximal (2) the teacher has not been able to concentrate students during the learning activities.3) the teacher has difficulties in applying the special principle learning thematic to the light mentally disabled children.
\end{abstract}

Keywords-mathematical thematic learning, mentally disabled students, qualitative research

\section{INTRODUCTION}

Education is a necessity for every human being to keep on growing his life for more dignity. Education is given to the degree of tampering possible. Education is a conscious and well-planned effort to realize the learning and learning process so that the participants will actively develop their potential to possess the spiritual power of religion, self-control, personality, intelligence, morality, and the skills they perceive, society [1]. A country has an obligation to provide quality educational services to each of the stakeholders exclusively in the case of specific needs.

Children with special needs or often called children with disabilities have special characteristics and abilities that are different from children in general. One of the limitations in children with special needs is the mentally disabled. Mentally disabled is a child with special needs who have below average intelligence that is ranged between 50-70. They are having experience barriers in doing any activity especially in learning. Mentally disabled students are a condition of the students whose have intelligence far below the average and is characterized by the limitation of intelligence and incompetence to the social communication [2].
Individuals deficient in memory skills, such as children and adults with learning disabilities (LD), would be expected to have difficulty on a number of academic and cognitive tasks [3]. Children with MLD have been found to have lower IQ scores than their typical achieving peers [4]

The characteristics that distinguish these children from their age mates. There are marked differences in factors linked to level of intellectual development, such as the ability to process information, the ability to acquire and use language, and emotional development. There are substantial differences, also, in the strengths that individual children bring to their development [5]. Intellectual disability is a board concept encompassing various intellectual deficts, including mental retardation (MR), various spesific condition such as specific learning disability, and problem acquired later in life thourgh acquired brain injuries. Since we study mathematics education, we will go into specific difficulties related to learning disability in mathematics [6].

Definitions of learning disabilities and learning difficulties vary and controversies over identification procedures, particularly the notion of a discrepancy between individuals' potential and their actual performance [7]. Learning materials for children with mentally disabled should be specified and wherever possible starting from concrete matters, considering they have limitations in abstract thinking. Teaching mathematics to children with light mentally disabled will be more successful if using something concrete, simple examples, understandable language, and done in an interesting and fun situation so that children with light mentally disabled are not saturated and motivated in learning.

Thematic learning is a learning system that enables student individually or actively seeking, digging, and discovering scientific concepts and principles holistically, meaningfully and authentically [8]. In the implementation of thematic learning there are several things need to be done include the planning stage, namely: mapping of competency standards that include the elaboration of competency standards and basic competencies, determining the theme, identification of competence, basic competence and indicators, setting the theme network, syllabus formulation, syllabus is the lesson plan on a particular group of subjects or themes covering 
competency standards, basic competencies, subject matter, learning activities, indicators of achievement of competencies for assessment, assessment, time allocation, and learning resources [9].

The problems in the application of thematic instruction are including: (1) A limitation of teachers' ability in performing games and kids songs; (2) Learning materials available are still using the approach of subjects, which results in teachers having difficulties in combining material according to the theme; (3) Thematic materials are still national-based, results in inappropriateness of materials in accordance with students' learning environment; (4) Team teaching model are appropriate with the schools applying the system of subject teachers. However, this model needs high coordination and commitment from each teacher; (5) On the other side, there are schools which are understaffing, results in teachers having difficulties in applying thematic instruction in first graders of elementary school; (6) Class teachers could use webbed model, i.e. using a particular theme as a learning principal for several subjects; (7) School environments in regencies which are still on the standard and the lacking technology due to inappropriate supporters; (8) Teachers and students making summaries in the end of learning activities everyday and in the end of a theme after several meetings; (9) Schedule of subjects which hinder the teachers in combining different subjects flexibly; and (10) The use of theme schedule which is more flexible in the thematic instruction but need more planning regarding the presentation's quality between subjects [10].

Basically in thematic learning, teachers are not only required to provide thematic learning but teachers are able to understand the characteristics of each student. From this background the writer focus on the application of principle of special thematic teaching to the light mentally disabled children.

\section{LITERATURE REVIEW}

Mathematics learning for children with light mentally disabled basically has the same principles with students in general but also must apply the special principles in learning [11]. Mentally disabled students have intellectual limitations bears so that learning for mentally disabled must be adjusted to its ability. Learning is done by giving the material section, and required continuous motivation from the teacher so that in the learning behavior change occurs towards a more positive.

\section{A. Special Principle Learning of Mentally Disabled Children)}

The special principles that teachers need to be noticed as follows: [12].

\section{1) Principles of Individual Needs-Based Education}

Learning which carried out in accordance with the needs that felt to be a problem should be planned with parents of students.

\section{2) Principles of Implementation of Behavior}

In providing guidance should be given step by step and done by using the target. If the child does not reach the expected target, then the execution time is extended, the target is re-analyzed, if necessary, can be broken down into a simpler part.

3) Relevant Principles with Daily Lives and Functional Skills in Families and Communities

4) Principles of learning conducted in schools based on the needs that exist in the family or community. Skills are taught in the form of optimization ability, so that at least mentally disabled children can care for itself independently.

5) The Principle of Interacting should be continuously with the Family

Interaction needs to exist between teachers and parents in the development achieved by mentally disabled children, therefore the development of children in school can be continued by parents at home. Parental support in the development of student skills is needed in order to implement meaningful learning.

\section{6) The Decelerating Behavior Principle}

Decelerating behavior is defined as a negative behavioral reduction. Many ways can be done so that this principle can run smoothly for example by giving rewards to children if able to withstand negative attitudes, punishment when the child performs a negative act. Prevent the situation or things that can trigger a negative attitude that appears.

\section{7) The Accelerating Behavior Principle}

This principle is done with the goal of creating habits and optimizing ability. Capability optimization is done by simple explanation as well as by assignment.

\section{B. The Format Of Learning Thematics Mathematics Of Light Mentally Disabled}

The mathematical learning of mathematics for light mentally disabled children can be done by the teacher as follows: [13].

1) Presenting a student with a picture and asking the student to name or describe the picture in mathematical terms,

2) Stating a term and asking the student to state a term with the opposite meaning (e.g., addition/subtraction),

3) Presenting the student with a written word and asking the student to mark a picture that shows a meaning for the word,

4) Presenting the student with a written word and four choices of responses and requesting that the student mark the word that is most similar in meaning to the standard,

5) Stating or writing a term and asking the student to write a definition for the term,

6) Stating or writing a term and asking the student to write the term in a sentence that defines the meaning of the term,

7) Presenting a task for the student to perform in which the key word signals the correct action. 


\section{RESEARCH AND METHOD}

This research is a qualitative descriptive research to understand and get a picture of how the teacher applying the principle of special learning for children with light mentally disable. Qualitative researchers strive to understand patterns, similarities and differences in the representations of participants' life worlds, as conveyed through interview transcripts, diaries, media recordings, field observations, etc [14].

The subject in this study is seventh grade Mathematics Teachers of SLB Negeri Purworejo, Purworejo District. The researchers conducted observations with observations on the ongoing process of thematic learning in light mentally disable classes using observation guidelines.

The researcher conducted this research with interviewing teachers to find out their understanding of the thematic principles of mathematical teaching of children with light mentally disable. The researcher asking about definitions, special principles and thematic mathematical learning steps for light mentally disable children.

To support the completeness of the data needed in the research used the documentation related to the activities of teachers in the implementation of mathematics thematic learning in the classroom of mentally disable. Documentation is done looking at the compatibility of files related to thematic learning such as mapping, Syllabus theme network, and lesson plan with the Curriculum Implementation Guideline 2013 Special Education.

\section{RESULTS AND DISCUSSION}

The learning reflection is the activity of teachers in evaluating the learning activities that have been done Reflection learning aims to determine the shortcomings of learning that has been done. Understanding the special principle of teaching thematic mathematics of mentally disable. The researcher asking about definitions, special principles and thematic mathematical children for teachers helps provide more meaningful learning. Teachers who are able to apply the special principles of children with mentally disable can improve the quality of learning and be able to solve mathematical problems.

This research uses observation, in-depth interview, and documentation of mathematics learning at the SLB Negeri Purworejo, Purworejo district. Observation done when the teacher taught mathematics in class aimed to know the learning process took place. Interview aims to know how far the teachers understand the special principle of thematic learning mathematics of children mentally disabled. Documentation of instructional devices is conducted to see if it is in accordance with the Special Education Curriculum 2013 Implementation Guideline. The following researchers will be presented with observation results in addition researchers also describe the interview results and documentation studies

A. Understanding Teacher Regarding Special Principles of Thematic Lesson of Math of Light Mentally Disabled Children.
Based on the results of field observation and in-depth interviews and documentation, it can be described that the seventh grade teacher of SLB Negeri Purworejo only understands the concept of thematic learning only, it can be seen that teachers in teaching and learning activities are still focused on one course only, yet it seems thematic linking some eyes students with one theme. Thematic lessons are only visible in the lesson plan only, which has combined several subjects into a theme.

The special principle on the learning of children with light mentally disable is not fully done by the teacher. At the time of learning, teachers tend to put more emphasis on affection towards students. Compassion for children with light mentally disable is very important because it gives warmth, cultivates a sense of acceptance and instills a sense of security.

Teacher said the special principle is a guide to give learning of mentally disable children. Special principles are difficult to apply in the classroom because the teacher has the obligation to finish the material. Teachers cannot explain the specific principles of teaching thematic mathematics of children with light mentally disable According to the teacher, there are two 2 principles of learning that must be considered in learning. The first principle the teacher must cultivate affection for the child. The teacher gives more intensive attention to the child is meant to make children feel comfortable and happy in learning. The second principle is the attitude, the difficulty in the child's mentally disable in the academic field, in particular due to the difficulty in thinking abstract. In learning the students have to experience firsthand, by being in the situation or environment in question or with the use of props. Learning is related to the experience of the students in everyday life.

B. Implementation Thematic Lesson of Math of Light Mentally Disabled Children.

\section{1) Preparation for Implementation of Learning}

Competency Standard Mapping (SK), Basic Competence (KD) and Indicator / Mapping Themes. The class teacher does not make the mapping himself, the teacher only takes care of the mapping made and given by the KKG / KKKS team. The teacher simply chooses a mapping that is easy to do without trying to make a more varied mapping in supporting learning. The teacher uses only the theme network guides that have been created. Teachers do not develop syllabus according to students' circumstances in the field. In the preparation of RPP teachers only copied from last year without making changes in accordance with the needs of learning. In this activity the teacher has not applied the principle of education based on individual needs. Teachers have not planned the learning according to the needs of the problem to the students.

\section{2) Implementation of Learning}

\section{a) Introductory Activities}

In the initial activities undertaken by the teacher is in accordance with the initial activity of thematic learning is to condition the class by asking the class president to prepare and pray. Teachers perform apperception and check the attendance of students. The teacher does not make a learning agreement and provides a clear footing to the students. 
the specific principles of teaching thematic mathematics Light Mentally Disabled Children. Special principles can only be done on some material and cannot be generalized. According to the teacher, there are two principles of thematic mathematics teaching Mentally Disabled Children, the principles are affection and demonstration.

The difficulties experienced by teachers are 1) the limited knowledge of teachers on the application of thematic learning models, 2) the limitations of their media, so the difficulty of determining the right media in linking the theme with the subjects combined, 3 ) teachers still find it difficult to determine the theme by the method that is appropriate with the combined subjects, so to overcome it should discuss it with fellow teachers in the KKG, 4) the teaching experience of teachers using thematic approach is still minimal, still find it difficult to present thematic learning to low-grade students, and most of the means to support thematic learning in schools tend to be limited, so they have difficulty in applying thematic learning.

\section{REFERENCES} give PR. Teachers sometimes give advice at the end of the meeting to increase activity in learning.

\section{3) Evaluation of Learning}

Assessment which done by the teacher during the lesson, the courage to answer the questions, the training had been given by teachers and the presence of students. At the evaluation stage the teacher does not interact with the parents continuously. Meeting with parents only done at the acceptance of learning outcomes in each semester so that the lack of support in the development of children's skills in order to implement meaningful learning.

\section{CONCLUSION}

Light Mentally Disabled students know and can do math but need a good idea of learning and assessment in order to provide a more meaningful learning. Thematic learning is a learning model that involves good concepts in a subject across subjects. The affection of the teacher gives comfort to the students in learning. The good application of the special principle of children's learning can provide feedback between teachers and students as well as teachers and parents. Learning done in schools based on the needs that exist in the family or community can provide the optimization of ability, so that at least Light Mentally Disabled Children can care for itself independently.

Based on the observation result with the observation obtained by the teacher in the class is less able to apply the special principle of thematic mathematics lesson of light Mentally Disabled. Learning is still general, there is no meaningful special treatment to students. Teachers are less able to condition students in mathematics thematic learning.

The results of interviews with the teachers of SLB Negeri Purworejo provide an illustration that teachers have difficulty in the application of special principles. Teachers cannot explain
[1] Undang-Undang Republik Indonesia Nomor 20 Tahun 2003 tentang Sistem Pendidikan Nasional.

[2] Kosasih, E. Cara Bijak Memahami Anak Berkebutuhan Khusus. Bandung: Yrama Widya, p. 80, 2012.

[3] Ruth Pearl, Mavis L. Donahue, Chapter 4 - Peer Relationships and Learning Disabilities, Editor(s): Bernice Wong, In Learning About Learning Disabilities (Third Edition), Academic Press, pp. 133-165, 2004.

[4] Katharina Lambert, Birgit Spinath, Are WISC IQ scores in children with mathematical learning disabilities underestimated? The influence of a specialized intervention on test performance, In Research in Developmental Disabilities, Volume 72, pp 56-66, 2018

[5] Kirk, S \& Gallagher, Educating Exceptional Children. Boston, USA: Houghton Miffilin Company, p.189, 2011.

[6] Pareto, L. Mathematical Literacy for Everyone Using Arithmetic games. Jurnal Ilmiah, p 02, 2012.

[7] Lorraine Graham, Anne Bellert, Chapter 7 - Difficulties in Reading Comprehension for Students with Learning Disabilities, Editor(s): Bernice Wong, In Learning About Learning Disabilities (Third Edition), Academic Press, pp. 251-279, 2004.

[8] Raka, Joni. Pembelajaran terpadu. Jakarta: Rajawali Pers, p. 03, 1993.

[9] Trianto. Pelaksanaan pembelajaran tematik kelas dasar. Bandung : Rosdakarya, p.25, 2007.

[10] Pudjiastuti, Ari. Problems in Applying Thematic Instruction in the First Grade of Elementary School. Dissertation, Instructional Technology Department, Post-Graduate Program, State University of Malang. pp.55-56, 2010.

[11] Kekeh, Lay. Manajemen Pendidikan Inklusif. Jakarta : Depdiknas, p. 176, 2007.

[12] Mumpuniarti. Pembelajaran Akademik bagi Tunaggrahita. Yogyakarta: FIP, pp. 53-56, 2007.

[13] Cawley, J. F., \& Parmar, R. S. Mathematics Assessment for Students With Mild Disabilities: Frameworks and Practices. Learning Disabilities -- A Contemporary Journal, 1(1), p. 21, 2003.

[14] Christen Erlingsson, Petra Brysiewicz, Orientation among multiple truths: An introduction to qualitative research, In African Journal of Emergency Medicine, Volume 3, Issue 2, pp. 92-99, 2013. 